\title{
Effect of Rootstock Type and Low Soil pH on Growth and Yield of 'Anna' and 'Jonagored' Cultivars.
}

\author{
Kebede Jobir, Masresha Fetene, Sheleme Beyene \\ Addis Ababa University College of Natural Science Department of Plant Biology and Biodiversity \\ Management, Ethiopia \\ kbutajobir@yahoo.com
}

\begin{abstract}
Acid soils are severe problems in many parts of Ethiopia, especially on the highland areas of the southern regions of the country. It is generally known that acid soils have adverse effects on growth and yield of apple trees. In view of the wide cultivation of apple in southern Ethiopia, this study was investigated the effect of different rootstocks (MM.111, MM.106 and M.9) and low soil pH (3.5, 4.9 and 6.3) treatments on vegetative growth and yield of Anna and Jonagored cultivars. The used research design was a factorial design in ten replicates. Features measured during the design included plant height, trunk diameter, leaf area, number of branches, leaf dry weight, total number of flowers and fruits. The soil pH of the study site was 4.9; the pH was adjusted, down to $\mathrm{pH} 3.5$ (in $\mathrm{H}_{2} \mathrm{SO}_{4}$ ) and higher to $\mathrm{pH} 6.3$ (in lime). Data on vegetative growth and yield components was followed for three years. The obtained results indicated that, 'Anna' and 'Jonagored' grafted on MM.106 rootstock had the least growth with least number of flowers and fruits in soil pH of 3.5. Under naturally occurring acidic soil ( $\mathrm{pH}$ 4.9) both 'Anna' and 'Jonagored' cultivars grafted on MM.111, MM.106, and M.9 produced reduced vegetative growth, mean number of flowers and fruits compared to soil pH of 6.3 . Both 'Anna' and 'Jonagored' grown on M.9 under soil pH of 6.3 produced more flower and fruits followed by MM.106 and least was found on MM.111. Among the two cultivars, more number of flowers and fruits were produced by 'Anna' than 'Jonagored'.
\end{abstract}

Keywords: apple, scion cultivars, rootstocks, growth, $p H$ levels.

\section{INTRODUCTION}

Rootstocks can markedly affect the vegetative growth of the scions. It has been reported that, rootstocks have significant effect on trunk diameter, plant height, leaf area, number of branches and yield of apple scions (Tahereh et al., 2011). Neeme et al. (2006) showed that, rootstock had a major influence not only on the growth vigour but also on number of flower clusters, fruit set and development per apple cultivars. The apple cultivar usually initiate flowers just after shoot growth ceases and when leaves are dropped (Frank and Dennis, 1996).The cultivars flower initiation and bud break depends on the vigour of rootstocks types and adequacy of cold temperature in which the cultivar grows (Westwood, 1993). Peter and David (1995) stated that, the effect of rootstock on flowering appears to be due to internal control mechanisms which affect the proportion of spurs that become floral. In agreement with this, several studies have showed that, apple rootstocks do influence the concentrations and movements of plant hormones (auxins, gibberellins, cytokinins and abscisic acid) within the tree (Soumelidou et al., 1994; Kamboj et al., 1997). It is likely that these differences are in some way involved in their influence on floral bud initiation in the scion. Other study reported that, rootstock effects on flowering may be due to differences among rootstocks in phosphorus uptake from the soil or differences in distribution within the tree which is positively related to rootstock vigour (Peter and David, 1995). Apple rootstock thus, shows differences on the growth vigour and blooming of cultivars grown on them.

Agriculture in Ethiopia is the main source of income in which about $81 \%$ of the population is engaged and generate revenue in the sector. Agriculture, accounting for about $45 \%$ of GDP and $85 \%$ of total employment, is the dominant sector in the national economy of Ethiopia

(CSA, 2010). Chencha is a highland area with naturally acidic soil (pH 4.9) due to mainly subsequent removal of crop residues, resulted in severe degradation of soil fertility and enhance soil acidity. The decline in soil fertility is making worse by soil erosion, which is aggravated by steep slopes, poor 
vegetation cover and continuous cropping. Presently, propagation of temperate fruits becomes an important component of development programs throughout the highlands of Ethiopia. Production and sales of apple fruits can have great contribution to the economy of farmers. Nowadays, the cultivation of apple trees by farmers is increased because of its importance as a source of income, since apple fruits as well as apple rootstocks used for grafting of scions are propagated and sold for apple growers within the country in relatively high price. The farmers have benefited from the high price, which increased their earnings and improved the livelihood of their family. Nevertheless, apple growing was not developed and expanded as it should be for a number of reasons among which knowledge on the impact of naturally occurring acidic soil in the area, and lack of information / on the degree of tolerance of rootstocks to low soil $\mathrm{pH}$ are considered to be the major ones. The present study was therefore carried out to assess the effect of low soil $\mathrm{pH}$ and selected rootstocks on growth and yield of Anna and Jonagored cultivars.

\section{MATERials AND MethodS}

\section{Location and Duration of Study}

This study was conducted at Chencha, in GamoGofa Zone of the SNNPRS of Ethiopia. The study site is situated $545 \mathrm{~km}$ south of Addis Ababa. This study was performed to evaluate the effect of different level of low soil $\mathrm{pH}$ and the impact of different rootstocks on vegetative growth and yield of Anna and Jonagored cultivars in 2011 to 2013 at Chencha farm land (Gamo Gofa).The research was set in polythene bags considered as micro-plots (Sas and Mercik, 2004). A total of 180 polythene bags having $85 \mathrm{~cm}$ height and $40 \mathrm{~cm}$ in diameter were filled with $40 \mathrm{~kg}$ of soil. The polythene bags contained soil with sufficient amounts of nutrients and one of three different pHs: $3.5,4.9$ and 6.3. Each polythene bag had only one pH level. Anna and Jonagored cultivars were grafted on MM.111, MM.106 and M.9 rootstocks that had been grown for three months in a polythene bag under similar $\mathrm{pH}$ levels and then allowed to grow for three years. The experiment consisted of 18 combinations with 10 replications, including 3 examined factors: $3 \mathrm{pH}$ levels 3.5, 4.9 and 6.3, three apple rootstocks M.106, M.111 and M.9, and 2 apple cultivars 'Anna' and 'Jonagored' $(10 \times 3 \times 3$ x $2=180)$ following Sas and Mercik (2004). Tree spacing between rows and blocks were 1.2 and $1.8 \mathrm{~m}$, respectively.

\section{Growth and Yield Measurements of Anna and Jonagored Cultivars}

Growth measurements were taken for both cultivars, 'Anna' and 'Jonagored' during their vigorous growth after winter dormancy for three seasons. Similarly flowers and fruits were counted for three successive seasons from October 2011 to November 2013 following (Sas and Merick, 2004; Przemyslaw and Maciej, 2006; Meland, 2009) metho

\section{Vegetative Growth}

A total of 30 fully developed leaves from ten replications were measured and the average leaf area $\left(\mathrm{cm}^{2}\right)$ was recorded. The scion shoot length of the replicates was measured $20 \mathrm{~cm}$ above the soil surface every year and the average was recorded. Similarly, the number of branches was counted following Esmaeil et al. (2001). Trunk circumference was measured on each tree every year after leaf drop (in August) at a premarked location $20 \mathrm{~cm}$ above the soil surface and converted to trunk cross sectional area (TCSA $\mathrm{cm}^{2}$ ) following Yahya and Teryl (2004) and Mohamed et al. (2012) method. At the end of the study year, leaf dry weight was determined destructively, gram of the sample of four fully developed leaves of 'Anna' and 'Jonagored' cultivars per replica. A total of forty leaves as a representative for ten replicates were dried in oven at $70^{\circ} \mathrm{C}$ to constant weight.

\section{Flowering}

Whole tree counts of clusters were made on each rootstock in ten replications to determine the rootstock's and low soil $\mathrm{pH}$ influence on flower cluster numbers. The number of flower clusters on each tree was counted within 2 to 3 days of full bloom, three times from October, 2011 to October, 2013. The spur of flower buds, which contain on average five flowers, were counted as one. Flower spurs that was damaged by frost was discarded. Counting was conducted from the bottom of the branch to the top. Each branch counted for their flower spur bud was marked to avoid repetition. The mean total number of flowers counted per cultivar was recorded per season. 


\section{Fruiting}

The whole tree of both 'Anna' and 'Jonagored' cultivars grafted on each rootstock were studied to determine the rootstock and low soil $\mathrm{pH}$ effect on fruit set. After pollination apple flower petals wilted within one to two weeks. The total number of fruit sets were counted following the wilting of bloom, and drop off of immature fruits within three weeks in every season from October 2011 to November2013. Yield was based on the mean total number of fruits counted per cultivar.

\section{Statistical Analysis}

The data were subjected to analysis of variance to find out treatment effects and/or interactions between factors. Analysis of variance was carried out using MINITAB statistical package version 14. The mean separation was performed by Duncan's multiple range tests at the level of the significance (LSD at $\mathrm{P}<0.05$ ) (Duncan, 1955). Sigma plot 10 was used to present the analyzed data in different graphs. The results were elaborated separately for each measurements value. Throughout the text, differences between treatment means is considered significant when $\mathrm{P}<0.05$.

\section{RESUlTS AND DisCUSSION}

Results of this study showed that, rootstocks used significantly $(\mathrm{p}<0.001)$ affected vegetative growth of both cultivars. Both Jonagored and Anna cultivars grafted on MM.111 revealed strongest vigour under $\mathrm{pH}$ level of 3.5(Table 1 and Table 6 respectively). Throughout the three growing season, large leaf area (Table 2 and 6 respectively) highest trunk growth, total height, more number of branches and leaf dry weight was noted for both Jonagored and 'Anna' grafted on MM.111 followed on M.9 (Table 3 and 4 respectively) and the thinnest trunk and smallest leaf area was recorded on MM.106 (Table 1 and 5, 2 and 6 respectively).

Table1. Effect of rootstock type and low soil pH on TCSA $\left(\mathrm{cm}^{2}\right)$ of 'Jonnagored' apple

\begin{tabular}{|c|c|c|c|c|c|c|c|c|c|}
\hline \multicolumn{10}{|c|}{ Jonnagored trunk cross sectional area $\left(\mathrm{cm}^{2}\right)$ per cultivar/year of growth } \\
\hline & \multicolumn{3}{|c|}{2011} & \multicolumn{3}{|c|}{2012} & \multicolumn{3}{|c|}{2013} \\
\hline $\mathrm{pH}$ & $\begin{array}{l}\text { Jonna } \\
\text { gored/ } \\
\text { MM111 }\end{array}$ & $\begin{array}{l}\text { Jonna } \\
\text { gored / } \\
\text { MM106 }\end{array}$ & $\begin{array}{l}\text { Jonna } \\
\text { gored / } \\
\text { M9 }\end{array}$ & $\begin{array}{l}\text { Jonna } \\
\text { gored / } \\
\text { MM111 }\end{array}$ & $\begin{array}{l}\text { Jonna } \\
\text { gored / } \\
\text { MM106 }\end{array}$ & $\begin{array}{l}\text { Jonna } \\
\text { gored / } \\
\text { M9 }\end{array}$ & $\begin{array}{l}\text { Jonna } \\
\text { gored / } \\
\text { MM111 }\end{array}$ & $\begin{array}{l}\text { Jonna } \\
\text { gored / } \\
\text { MM106 }\end{array}$ & $\begin{array}{l}\text { Jonna } \\
\text { gored / } \\
\text { M9 }\end{array}$ \\
\hline 3.5 & $2.5 \pm .08 b$ & $2.1 \pm .28 b$ & $3.4 \pm .08 b$ & $4.5 \pm .08 b$ & $3.7 \pm .28 b$ & $3.4 \pm .08 b$ & $5.7 \pm .08 b$ & $3.2 \pm .01 b$ & $4.8 \pm .08 b$ \\
\hline 4.9 & $3.5 \pm .08 \mathrm{a}$ & $3.9 \pm .08 a$ & $4.1 \pm .55 b$ & $4.5 \pm .08 \mathrm{a}$ & 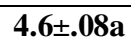 & $4.1 \pm .55 \mathrm{~b}$ & $5.7 \pm .43 b$ & $4.75 \pm .03 \mathrm{~b}$ & $5.1 \pm .01 b$ \\
\hline 6.3 & $3.7 \pm .33 a$ & $4.1 \pm .55 a$ & $6.1 \pm .55 a$ & $7.7 \pm .33 a$ & $6.1 \pm .55 a$ & $9.1 \pm .55 a$ & $10.9 \pm .16 a$ & $8.6 \pm 0.1 a$ & $12.2 \pm 5.04 a$ \\
\hline
\end{tabular}

Means with same letters in columns indicate non-significant differences at $\mathrm{P}<0.05$ by Duncan test. Letters across soil $\mathrm{pH}$ (columns) indicated differences between same cultivar/rootstock combinations under different level of soil $\mathrm{pH}$.

Table2. Effect of root stock type and low soil pH on Leaf area $\left(\mathrm{cm}^{2}\right)$ of 'Jonnagored' apple.

\begin{tabular}{|c|c|c|c|c|c|c|c|c|c|}
\hline \multicolumn{10}{|c|}{ Jonagored leaf area per cultivar/year of growth } \\
\hline & \multicolumn{3}{|c|}{2011} & \multicolumn{3}{|c|}{2012} & \multicolumn{3}{|c|}{2013} \\
\hline $\mathrm{pH}$ & \begin{tabular}{|l} 
Jonna \\
gored/ \\
MM111
\end{tabular} & $\begin{array}{l}\text { Jonna } \\
\text { gored / } \\
\text { MM106 }\end{array}$ & $\begin{array}{l}\text { Jonna } \\
\text { gored / } \\
\text { M9 }\end{array}$ & $\begin{array}{l}\text { Jonna } \\
\text { gored / } \\
\text { MM111 }\end{array}$ & \begin{tabular}{|l} 
Jonna \\
gored / \\
MM106
\end{tabular} & $\begin{array}{l}\text { Jonna } \\
\text { gored / } \\
\text { M9 }\end{array}$ & $\begin{array}{l}\text { Jonna } \\
\text { gored / } \\
\text { MM111 }\end{array}$ & $\begin{array}{l}\text { Jonna } \\
\text { gored / } \\
\text { MM106 }\end{array}$ & $\begin{array}{l}\text { Jonna } \\
\text { gored / } \\
\text { M9 }\end{array}$ \\
\hline 3.5 & $15.2 \pm .3 \mathrm{~b}$ & $9.7 \pm 3.2 \mathrm{~b}$ & $13.9 \pm .4 b$ & $18.2 \pm .1 b$ & $13.7 \pm 2.2 \mathrm{~b}$ & $17.9 \pm .61 b$ & $25.3 \pm .84 b$ & $18.7 \pm 1.2 b$ & $20.9 \pm .61 b$ \\
\hline 4.9 & $17.1 \pm .1 \mathrm{a}$ & $11.5 \pm .54 b$ & $16.8 \pm .9 b$ & 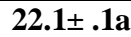 & $18.5 \pm .84 \mathrm{~b}$ & $20.8 \pm .62 b$ & $29.1 \pm 1.1 a$ & $22.5 \pm .84 b$ & $21.8 \pm .62 b$ \\
\hline 6.3 & $20.8 \pm .1 b$ & $20.9 \pm .9 a$ & $22.7 \pm .7 \mathbf{a}$ & $23.8 \pm .1 b$ & $25.2 \pm .9 \mathrm{a}$ & $30.7 \pm 2.7 a$ & $25.8 \pm 1.1 b$ & $28.2 \pm .3 a$ & $39.7 \pm 2.7 a$ \\
\hline
\end{tabular}

Means with same letters in columns indicate non-significant differences at $\mathrm{P}<0.05$ by Duncan test. Letters across soil $\mathrm{pH}$ (columns) indicated differences between same cultivar/rootstock combinations under different level of soil $\mathrm{pH}$.

Increased trunk growth and leaf area was recorded with an increase in soil $\mathrm{pH}$ to 4.9 for both cultivars with highest value for Anna grafted on MM.111 and Jonagored on M.9. Total plant growth (height, number of branches, trunk and leaf growth) was higher for both cultivars grown under $\mathrm{pH} 6.3$ than $\mathrm{pH}$ 3.5 or 4.9 (Table 3 and 4). The result showed MM.111 as the most vigorous rootstocks under strongly acidic soil whereas MM.106 was least while M.9 was intermediate. In contrast, with an increase in level of soil pH to 6.3, MM.111 was in second rank compared to M.9 rootstock. Both 'Jonagored' and 'Anna' grown on M.9 had thickest TCSA, followed on MM.111 and thinnest on MM.106 throughout the three successive growing season (Table 1 and 5 respectively). 
Kebede Jobir et al.

Table3. Effect of rootstock type, low soil pH and its interaction on vegetative growth of 'Jonagored' cultivar.

\begin{tabular}{|l|l|l|l|l|}
\hline \multirow{2}{*}{$\begin{array}{l}\text { Cultivar/ } \\
\text { Rootstocks }\end{array}$} & Vegetative growth & $\mathrm{pH}$ & \multicolumn{3}{|l|}{} \\
\cline { 2 - 5 } & & 3.5 & 4.9 & 6.3 \\
\hline \multirow{4}{*}{$\begin{array}{l}\text { 'Jonagored' } \\
\text { /MM.111 }\end{array}$} & Total height(m) & $0.93 \pm 5.9 . \mathrm{c}$ & $1.17 \pm 9.2 \mathrm{~b}$ & $1.34 \pm 7.5 \mathrm{a}$ \\
\cline { 2 - 5 } & Total branches & $2.5 \pm .08 \mathrm{~b}$ & $2.7 \pm .08 \mathrm{~b}$ & $7 \pm .08 \mathrm{a}$ \\
\cline { 2 - 5 } & LDW(g) & $18.4 \pm .50 \mathrm{c}$ & $20.1 \pm .53 \mathrm{~b}$ & $23.0 \pm .56 \mathrm{a}$ \\
\hline $\begin{array}{l}\text { 'Jonagored' } \\
\text { /MM.106 }\end{array}$ & Total height(m) & $0.85 \pm 6.9 \mathrm{~b}$ & $1.02 \pm 8.4 \mathrm{~b}$ & $1.15 \pm 5.3 \mathrm{a}$ \\
\cline { 2 - 5 } & Total branches & $1.4 \pm .08 \mathrm{~b}$ & $3.0 \pm .4 \mathrm{a}$ & $4.5 \pm .08 \mathrm{~b}$ \\
\cline { 2 - 5 } & LDW(g) & $14.2 \pm .50 \mathrm{~b}$ & $18.2 \pm .40 \mathrm{a}$ & $19.6 \pm .51 \mathrm{a}$ \\
\hline \multirow{2}{*}{$\begin{array}{l}\text { 'Jonagored' } \\
\text { /M.9 }\end{array}$} & Total height(m) & $0.87 \pm 11 \mathrm{a}$ & $.98 \pm 10.5 \mathrm{a}$ & $1.15 \pm 10.4 \mathrm{a}$ \\
\cline { 2 - 5 } & Total branches & $2.4 \pm .08 \mathrm{a}$ & $2.8 \pm . .08 \mathrm{a}$ & $3.10 \pm .4 \mathrm{a}$ \\
\cline { 2 - 5 } & LDW $(\mathrm{g})$ & $16.7 \pm .67 \mathrm{~b}$ & $19.0 \pm .51 \mathrm{~b}$ & $20.7 \pm .47 \mathrm{a}$ \\
\hline
\end{tabular}

Means with same letters in rows indicate non-significant differences at $\mathrm{P}<0.05$ by Duncan test. Letters across soil $\mathrm{pH}$ indicated differences between same rootstock under different level of soil $\mathrm{pH}$.

Table4. Effect of rootstock type, low soil $\mathrm{pH}$ and its interaction on vegetative growth of 'Anna.

\begin{tabular}{|l|l|l|l|l|}
\hline \multirow{2}{*}{$\begin{array}{l}\text { Cultivar/ } \\
\text { Rootstocks }\end{array}$} & Growth Parameters & \multicolumn{3}{|c|}{$\mathrm{pH}$} \\
\cline { 3 - 5 } \multirow{2}{*}{$\begin{array}{l}\text { Anna/ } \\
\text { MM.111 }\end{array}$} & Total height(m) & 1.5 & 4.9 & 6.3 \\
\cline { 2 - 5 } & Total branches & $3.8 \pm .08 \mathrm{~b}$ & $6.1 \pm .08 \mathrm{a}$ & $5.4 \pm .08 \mathrm{a}$ \\
\cline { 2 - 5 } & LDW(g) & $19.3 \pm .56 \mathrm{~b}$ & $21.1 \pm .56 \mathrm{a}$ & $22.3 \pm 1.6 \mathrm{a}$ \\
\hline $\begin{array}{l}\text { Anna/ } \\
\text { MM.106 }\end{array}$ & Total height(m) & $1.01 \pm 12.03 \mathrm{~b}$ & $1.08 \pm 10.6 \mathrm{~b}$ & $1.24 \pm 5.3 \mathrm{a}$ \\
\cline { 2 - 5 } & Total branches & $2.3 \pm .05 \mathrm{~b}$ & $2.4 \pm .05 \mathrm{~b}$ & $5.6 \pm .08 \mathrm{a}$ \\
\cline { 2 - 5 } & LDW(g) & $15.1 \pm .75 \mathrm{~b}$ & $21.1 \pm .63 \mathrm{a}$ & $21.9 \pm .56 \mathrm{a}$ \\
\hline $\begin{array}{l}\text { Anna/ } \\
\text { M.9 }\end{array}$ & & & & \\
\cline { 2 - 5 } & Total height(m) & $.91 \pm 11.6 \mathrm{~b}$ & $.98 \pm 10.5 \mathrm{~b}$ & $1.05 \pm 12.2 \mathrm{a}$ \\
\cline { 2 - 5 } & Total branches & $3.2 \pm .11 \mathrm{c}$ & $4.4 \pm .08 \mathrm{~b}$ & $5.7 \pm .08 \mathrm{a}$ \\
\cline { 2 - 5 } & LDW(g) & $17.1 \pm .59 \mathrm{a}$ & $18.2 \pm .75 \mathrm{a}$ & $18.05 \pm 1.9 \mathrm{a}$ \\
\hline
\end{tabular}

Means with same letters in rows indicate non-significant differences at $\mathrm{P}<0.05$ by Duncan test. Letters across soil $\mathrm{pH}$ indicated differences between same rootstock under different level of soil $\mathrm{pH}$.

The growth parameters were significantly different under naturally occurring acidic soil ( $\mathrm{pH} 4.9$ ). Both cultivars grown on MM.106 and M.9 registered differences in total number of branches. Highest was recorded for 'Anna' on M.9 whereas 'Jonagored' recorded highest on MM.106 (Table 4 and 3). 'Anna' on MM.111 recorded high growth in leaf dry weight, and total height followed on M.9 while least was found on MM.106 (Table 4). Conversely, 'Jonagored' grown on MM.111 recorded high growth in total height, followed on MM.106 and least was found on M.9. However, more growth of 'Jonagored' leaf dry weight was found on M.9 rootstock (Table 3). This showed that, the difference in scion rootstocks combination resulted in performance differences among the rootstocks under similar soil $\mathrm{pH}$. Thus, before planting selection of compatible rootstocks seems to be very important.

Table5. Effect of rootstock type and low soil pH on TCSA $\left(\mathrm{cm}^{2}\right)$ of 'Anna' per year of growth.

\begin{tabular}{|l|l|l|l|l|l|l|l|l|l|}
\hline \multicolumn{9}{|c|}{ Anna trunk cross sectional area $\left(\mathrm{cm}^{2}\right)$ per cultivar/year } \\
\hline \multirow{3}{*}{$\mathrm{pH}$} & \multicolumn{3}{c|}{2012} & \multicolumn{3}{c|}{2013} \\
\cline { 2 - 11 } & Anna/ & Anna/ & Anna/ & Anna/ & Anna/ & Anna/ & Anna/ & Anna/ & Anna/ \\
& MM111 & MM106 & M9 & MM111 & MM106 & M9 & MM111 & MM106 & M9 \\
\hline 3.5 & $3.5 \pm .51 \mathrm{a}$ & $1.96 \pm .18 \mathrm{c}$ & $3.1 \pm .50 \mathrm{~b}$ & $4.5 \pm .51 \mathrm{a}$ & $3.96 \pm .18 \mathrm{c}$ & $4.1 \pm .50 \mathrm{~b}$ & $6.2 \pm .09 \mathrm{~b}$ & $4.6 \pm .08 \mathrm{c}$ & $5.5 \pm .08 \mathrm{c}$ \\
\hline 4.9 & $3.7 \pm .35 \mathrm{a}$ & $2.6 \pm .31 \mathrm{~b}$ & $3.6 \pm .17 \mathrm{~b}$ & $5.7 \pm .35 \mathrm{a}$ & $4.6 \pm .31 \mathrm{~b}$ & $4.6 \pm .17 \mathrm{~b}$ & $6.9 \pm .08 \mathrm{a}$ & $5.7 \pm .08 \mathrm{~b}$ & $6.0 \pm .08 \mathrm{~b}$ \\
\hline 6.3 & $4.1 \pm .55 \mathrm{a}$ & $4.06 \pm .33 \mathrm{a}$ & $5.6 \pm .17 \mathrm{a}$ & $6.1 \pm .55 \mathrm{a}$ & $5.06 \pm .33 \mathrm{a}$ & $7.6 \pm .17 \mathrm{a}$ & $6.9 \pm .08 \mathrm{a}$ & $6.1 \pm .08 \mathrm{a}$ & $8.5 \pm .08 \mathrm{a}$ \\
\hline
\end{tabular}

Means with same letters in columns indicate non-significant differences at $\mathrm{P}<0.05$ by Duncan test. Letters across soil $\mathrm{pH}$ (columns) indicated differences between same cultivar/rootstock combinations under different level of soil $\mathrm{pH}$. 
Table6. Effect of rootstock type, low soil pH on Leaf area $\left(\mathrm{cm}^{2}\right)$ of 'Anna'per year of growth.

\begin{tabular}{|c|c|c|c|c|c|c|c|c|c|}
\hline \multicolumn{10}{|c|}{ Anna leaf area $\left(\left(\mathrm{cm}^{2}\right)\right.$ per cultivar/year of growth } \\
\hline \multicolumn{4}{|c|}{2011} & \multicolumn{3}{|l|}{2012} & \multicolumn{3}{|l|}{2013} \\
\hline $\mathrm{pH}$ & $\begin{array}{l}\text { Anna/ } \\
\text { MM111 }\end{array}$ & $\begin{array}{l}\text { Anna/ } \\
\text { MM106 }\end{array}$ & $\begin{array}{l}\text { Anna/ } \\
\text { M9 }\end{array}$ & $\begin{array}{l}\text { Anna/ } \\
\text { MM111 }\end{array}$ & $\begin{array}{l}\text { Anna/ } \\
\text { MM106 }\end{array}$ & $\begin{array}{l}\text { Anna/ } \\
\text { M9 }\end{array}$ & $\begin{array}{l}\text { Anna/ } \\
\text { MM111 }\end{array}$ & $\begin{array}{l}\text { Anna/ } \\
\text { MM106 }\end{array}$ & $\begin{array}{l}\text { Anna/ } \\
\text { M9 }\end{array}$ \\
\hline 3.5 & $14.1 \pm .3 b$ & 11.2 $\pm 1.2 \mathrm{~b}$ & $12.7 \pm .3 \mathrm{~b}$ & $22.2 \pm 1.3 b$ & $16.2 \pm 1.4 \mathrm{~b}$ & $20.7 \pm 1.3 b$ & $30.2 \pm .1 \mathrm{~b}$ & $21.03 \pm .6 b$ & $23.9 \pm 1.1 b$ \\
\hline 4.9 & $20.5 \pm .3 b$ & $16.2 \pm 1.0 \mathrm{~b}$ & $17 . .5 \pm .7 b$ & $25.9 \pm 1.5 b$ & $20.02 \pm 1 b$ & $22.5 \pm .7 b$ & $32.9 \pm .5 b$ & $25.06 \pm .3 b$ & $24.8 \pm .78 b$ \\
\hline 6.3 & $27.5 \pm 2 a$ & $24.1 \pm .8 \mathrm{a}$ & $22.3 \pm .9 a$ & $32.5 \pm 2.6 a$ & $27.1 \pm 1.8 a$ & $24.3 \pm .9 \mathrm{a}$ & $49.6 \pm 3 a$ & $37.0 \pm 2.8 a$ & $28.8 \pm 1.9 a$ \\
\hline
\end{tabular}

Means with same letters in columns indicate non-significant differences at $\mathrm{P}<0.05$ by Duncan test. Letters across soil pH (columns) indicated differences between same cultivar/rootstock combinations under different level of soil $\mathrm{pH}$.

\section{Mean Number of Flowers}

The number of flowers of 'Anna' and 'Jonagored' was significantly $(p<0.001)$ affected by low soil $\mathrm{pH}$ and rootstock type. Despite the differential growth associated with $\mathrm{pH}$ treatments, number of flowers showed the respond of rootstocks to soil acidification. The flower production was increased with an increase in level of soil $\mathrm{pH}$ and year of growth. The highest was counted in soil $\mathrm{pH}$ of 6.3 and end of growing season, 2013 while least was in $\mathrm{pH} 3.5$ and first fruit bearing season 2011. The number of flowers in 2011 was few due to early growing season. Jonagored and Anna grafted on MM.111grew vigorously and produce more flowers while weaker on MM.106 and produce least than on M.9 under soil $\mathrm{pH}$ of 3.5 (Table 7 and 8). Under naturally occurring acidic soil ( $\mathrm{pH} 4.9$ ), in the growing season of 2012 and 2013 Jonagored grafted on M.9 and MM.106 produced more number of flowers while least was found on MM.111(Table 7). In contrast Anna on MM.111 produced more number of flowers while least on MM.106 and intermediate on M.9 (Table 8).

Table7. Flowering of Jonagored as influenced by different rootstocks and low soil pH treatments.

\begin{tabular}{|c|c|c|c|c|c|c|c|c|c|}
\hline \multicolumn{10}{|c|}{ Number of flowers per cultivar } \\
\hline & \multicolumn{3}{|c|}{2011} & \multicolumn{3}{|c|}{2012} & \multicolumn{3}{|c|}{2013} \\
\hline $\mathrm{pH}$ & $\begin{array}{c}\text { Jonna } \\
\text { gored/ } \\
\text { MM111 }\end{array}$ & $\begin{array}{c}\text { Jonna } \\
\text { gored / } \\
\text { MM106 }\end{array}$ & $\begin{array}{c}\text { Jonna } \\
\text { gored / } \\
\text { M9 }\end{array}$ & $\begin{array}{c}\text { Jonna } \\
\text { gored / } \\
\text { MM111 }\end{array}$ & $\begin{array}{l}\text { Jonna } \\
\text { gored / } \\
\text { MM106 }\end{array}$ & $\begin{array}{c}\text { Jonna } \\
\text { gored / } \\
\text { M9 }\end{array}$ & $\begin{array}{l}\text { Jonna } \\
\text { gored / } \\
\text { MM111 }\end{array}$ & $\begin{array}{l}\text { Jonna } \\
\text { gored / } \\
\text { MM106 }\end{array}$ & $\begin{array}{c}\text { Jonna } \\
\text { gored / } \\
\text { M9 }\end{array}$ \\
\hline 3.5 & 8 & 4 & 7 & 10 & 12 & 11 & 11 & 16 & 20 \\
\hline 4.9 & 10 & 8 & 11 & 11 & 14 & 16 & 13 & 19 & 24 \\
\hline 6.3 & 12 & 11 & 13 & 14 & 17 & 19 & 17 & 22 & 28 \\
\hline
\end{tabular}

In growing season of 2012 and 2013, the flower formation of 'Jonagored' grafted on MM.106 increased under soil $\mathrm{pH}$ of 6.3 while least on MM.111. In contrast, under similar soil pH 'Anna' grown on MM.106 showed least flower formation while highest was recorded on MM.111 (Table 7 and 8 respectively). This showed that, unlike Jonagored, Anna was not productive on MM.106. Thus, the types of rootstocks determine the flower production of cultivars under similar $\mathrm{pH}$ treatments. In soil $\mathrm{pH}$ of 6.3 the highest number of flowers was counted for Jonagored grafted on M.9 throughout the growing seasons compared to other two rootstocks while for Anna, more flowering was recorded in 2011 and end of growing season, 2013 (Table 7 and 8 respectively).

Table8. Flowering of Anna as influenced by different rootstocks and low soil pH treatment

\begin{tabular}{|c|c|c|c|c|c|c|c|c|c|}
\hline \multicolumn{9}{|c|}{ Number of flowers per cultivar/year } \\
\hline \multirow{3}{*}{$\mathrm{pH}$} & \multicolumn{3}{|c|}{2011} & \multicolumn{4}{c|}{2012} & \multicolumn{2}{c|}{2013} \\
\cline { 2 - 11 } & $\begin{array}{c}\text { Anna/ } \\
\text { MM111 }\end{array}$ & $\begin{array}{c}\text { Anna/ } \\
\text { MM106 }\end{array}$ & $\begin{array}{c}\text { Anna/ } \\
\text { M9 }\end{array}$ & $\begin{array}{c}\text { Anna/ } \\
\text { MM111 }\end{array}$ & $\begin{array}{c}\text { Anna/ } \\
\text { MM106 }\end{array}$ & $\begin{array}{c}\text { Anna/ } \\
\text { M9 }\end{array}$ & $\begin{array}{c}\text { Anna/ } \\
\text { MM111 }\end{array}$ & $\begin{array}{c}\text { Anna/ } \\
\text { MM106 }\end{array}$ & $\begin{array}{c}\text { Anna/ } \\
\text { M9 }\end{array}$ \\
\cline { 2 - 11 }$y$ & & & & & & & & & \\
\hline 3.5 & 13 & 4 & 6 & 15 & 8 & 11 & 24 & 13 & 18 \\
\hline 4.9 & 14 & 10 & 8 & 19 & 13 & 17 & 20 & 18 & 27 \\
\hline 6.3 & 16 & 12 & 17 & 23 & 16 & 20 & 28 & 19 & 36 \\
\hline
\end{tabular}

\section{Mean Number of Fruits}

The effect of low soil $\mathrm{pH}$ on fruit set of both 'Jonagored' and 'Anna' was statistically significant ( $\mathrm{p}<$ 0.001).The differences in fruit set were determined by degree of rootstocks tolerance to the effect of low soil $\mathrm{pH}$. Minimum number of fruits was registered for 'Anna' and 'Jonagored' in soil $\mathrm{pH}$ of 3.5 with progressive increase in $\mathrm{pH} 4.9$ and with maximum fruit number in soil $\mathrm{pH}$ of 6.3 under all three 
successive seasons (Fig.1 and 2 respectively). This indicated that, soil pH below 6.3 significantly decreased the yield of both 'Anna' and 'Jonagored' cultivar under study site.

According to data of 2011, 2012, and 2013, the number of fruits registered for both 'Anna' and 'Jonagored' differs on type of rootstocks, level of soil $\mathrm{pH}$ and year of growth. The fruit production of both cultivars increased with increase in level of soil $\mathrm{pH}$ to 6.3 and year of growth, 2013. Conversely least fruit count was obtained under pH 3.5 and in growing season of 2011(Fig 1 and 2 respectively).

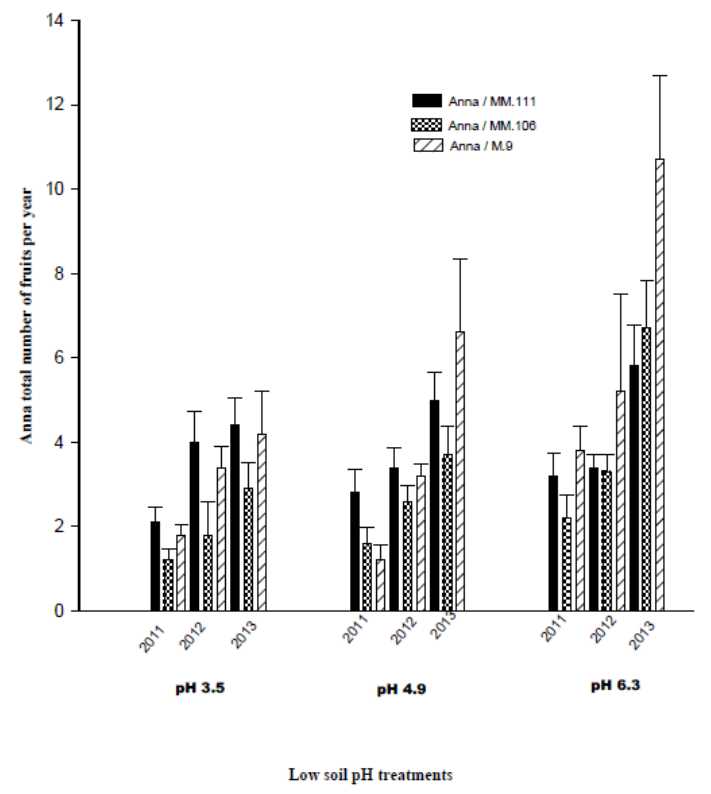

Figure1. Effect of rootstock type and low soil pH on number of 'Anna' fruits per three successive seasons.

In all three successive seasons both cultivars on MM.106 were the least productive under strongly acidic soil of $\mathrm{pH} 3.5$. In this soil $\mathrm{pH}$, we observed poorly developed few number of spur leaves surrounding early fruit set. A healthy and abundant supply of spur leaves is crucial for the set and early development of the fruit of apple trees (Webster, 2005). The number of fruits counted for both 'Jonagored' and 'Anna' cultivars showed statistically significant differences $(p<0.001)$. Throughout the three successive years, 'Anna' grafted on MM.111produced highest number of fruits, lowest on M.9 and least was recorded on MM.106 under acidic soil of pH 3.5 (Fig 1). Similar results with rootstock types but with more number of fruits were recorded for 'Jonagored' on MM.111 followed on M.9 and least was on MM.106 under low soil pH of 3.5 (Fig 2). The results showed that, 'Anna' with more flowers than 'Jonagored' on three rootstocks produced less fruits indicated flower shading and fruit drop of 'Anna' in low soil pH of 3.5 was more compared to 'Jonagored' grown under similar conditions in all growing seasons. Both cultivars were recommended to be grafted on MM.111 and M.9 rootstocks. The only rootstock under study which appears to affect fruit set negatively was MM.106 in soil $\mathrm{pH}$ of 3.5.

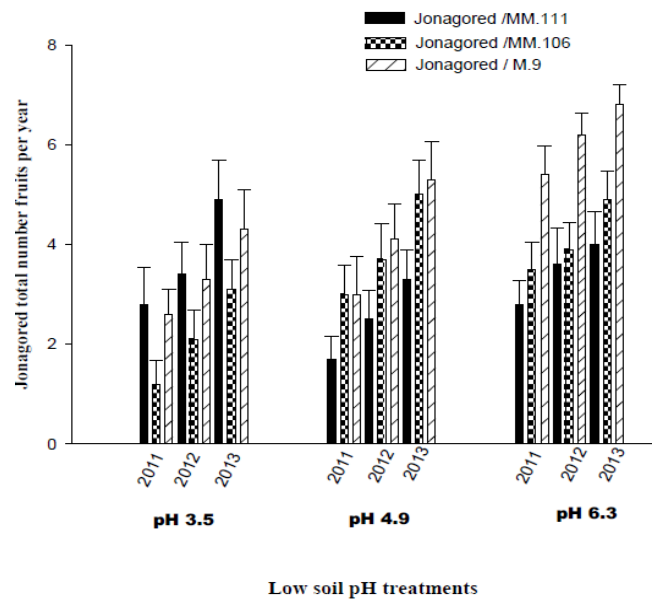

Figure2. Effect of rootstock type and low soil pH on number of 'Jonagored' fruits per three successive seasons. 
Under naturally acidic soil ( $\mathrm{pH}$ 4.9), 'Anna' on MM.111 produced more fruits followed on MM.106 and least was counted on M.9 in the first growing season while, in the second and third Anna was more productive on MM.111 and M.9 respectively but least on MM.106 (Fig 1). In contrast, highest number of fruits was recorded for 'Jonagored' grown on MM.106 and M.9 in ranking order and least was found on MM.111 in all three successive seasons (Fig 2). This contrasting differences between the two cultivars indicated differences in the effect of rootstocks and low soil $\mathrm{pH}$ interaction on fruit production of the scions. Contrasting results were found in flower formation and fruit set for 'Anna' grafted on MM.111 and M.9 rootstocks in soil pH of 4.9. We observed that, 'Anna' on MM.111 produced more flowers than 'Anna' on M.9 in first growing season. However, comparing the amount of flowers produced with the number of fruit set, we found more for 'Anna' grown on M.9 compared to MM.111 indicated flower shading and failure of fruit set of 'Anna' on MM.111was more compared to M.9 (Fig 1). In soil pH of 4.9 more fruit drop was observed compared to $\mathrm{pH}$ 6.3. The main possible explanation was the shortage of essential nutrient uptake and translocation by rootstocks due to accumulation of soluble toxic elements. This caused leaves to send insufficient photosynthetic products to the fruit which could result in an imbalance in the hormones within the fruit and which leads to fruit drops as reported by Webster (2005). This study therefore showed that, the fruit yield of the cultivars grown under naturally occurring acidic soil of study site was severely affected.

Under soil pH of 6.3, 'Anna' on all rootstocks registered highest number of fruits than 'Jonagored' in all seasons. The highest number of fruits was registered for 'Anna' grown on M.9 followed on MM.111 and least was found on MM.106 (Fig 1). Conversely, 'Jonagored' grafted on M.9 produced more fruits followed on MM.106 whereas least fruit number was recorded for 'Jonagored' grown on MM.111 (Fig 2).This indicated that, the productivity of both cultivars grafted on M.9 increased with an increase in soil pH. High fruit set of both 'Anna' and 'Jonagored' grown on dwarf M.9 rootstock confirms its increase in potential uptake and transport of minerals with an increase in soil pH to 6.3. MM.111 with vigorous performance than other two rootstocks under decreased soil $\mathrm{pH}$ of 3.5 and 4.9 failed adequate fruit set in both cultivars under $\mathrm{pH}$ of 6.3. Thus, in this study site MM.111 was not recommended under higher soil $\mathrm{pH}$ condition.

The fruit set of both 'Jonagored' and 'Anna' increased with an increase in thickness of trunk diameter across low soil $\mathrm{pH}$. Significant positive correlation coefficient was recorded between trunk diameter, leaf area and number of fruits (Table 9 and 10 respectively) under all growing season. The size of leaf and number of fruits increased with an increase in trunk size throughout the seasons. This agrees with previous results of Wesley and James (2001) who reported that, apple cultivars cumulative yield had close relationship with trunk cross sectional area. MM.106 with thinnest TCSA for both cultivars produced minimum fruits indicated, cultivars on weaker stocks produced less wood with few number of fruits whereas MM.111 with thickest produced maximum fruits under soil $\mathrm{pH}$ of 3.5. This showed that, vigorous MM.111 rootstock produced the most wood which produced it faster in the first season of growth, form more fruits. However, both cultivars grown on MM.111 showed thinnest TCSA in soil $\mathrm{pH}$ of 6.3 produced least fruits compared to M.9 and MM.106. Our result agrees with Esmaeli et al. (2002) who reported that, Fuji apple cultivars on MM.111was least productive and produced the lowest amount of yield than MM.106 and M. 9 in high soil pH of Parma.

Table9. Correlation coefficient of 'Jonagored' TCSA, LA, and number of fruits.

\begin{tabular}{|c|c|c|c|c|}
\hline Source & & TCSA & LA & Fruits \\
\hline \multirow[t]{2}{*}{ TCSA } & Pearson Correlation & 1 & $.461^{* *}$ & $.448^{* * *}$ \\
\hline & Sig. (2-tailed) & & .000 & .000 \\
\hline \multirow[t]{2}{*}{ LA } & Pearson Correlation & $.461^{* * *}$ & 1 & .202 \\
\hline & Sig. (2-tailed) & .000 & & .056 \\
\hline \multirow[t]{2}{*}{ Fruits } & Pearson Correlation & $.448^{* * *}$ & .202 & 1 \\
\hline & Sig. (2-tailed) & .000 & .056 & \\
\hline
\end{tabular}

M.9 with thickest TCSA for both cultivars recorded highest fruit count under soil pH of 6.3 . Compared with MM.106, 'Anna' and 'Jonagored' grown on M.9 produced highest fruit number. In another study, Sotiropoulos (2008) reported that, Imperial cultivar grafted on MM.106 produced high yield than on M.9 under soil pH of 6.8 in Greece. This confirmed differences in rootstocks performance from area to area. Researchers revealed that, apple rootstocks performance differed due to scion rootstock interaction or due to inconsistent of rootstocks from site to site as well as from region to region (Yahya et al., 2004). 
Kebede Jobir et al.

Table10. Correlation coefficient of 'Anna' TCSA, LA, and number of fruits.

\begin{tabular}{|c|c|c|c|c|}
\hline \multirow{2}{*}{ Source } & & TCSA & LA & Fruits \\
\hline \multirow{2}{*}{ LCSA } & Pearson Correlation & 1 & $.430^{* *}$ & $.352^{* *}$ \\
\cline { 2 - 5 } & Sig. (2-tailed) & & .000 & .001 \\
\cline { 2 - 5 } & Pearson Correlation & $.430^{* * *}$ & 1 & -.095 \\
\hline \multirow{2}{*}{ Fruits } & Sig. (2-tailed) & .000 & & .375 \\
\cline { 2 - 5 } & Pearson Correlation & $.352^{* *}$ & -.095 & 1 \\
\hline \multicolumn{2}{|r|}{ Sig. (2-tailed) } & .001 & .375 & \\
\hline
\end{tabular}

On basis of obtained results, rootstocks had significant influence on number of fruits. Under strongly acidic soil of $\mathrm{pH} 3.5$ both 'Anna'and 'Jonagored' had more number of fruits on MM.111 followed on M.9, and least was found on MM.106 rootstock (Fig. 1 and 2 respectively). Our study agrees with Sas and Mercik (2004) for M.9 who reported, Gala and Jonagold fruits were highest on rootstock P.22, less on M.9 and fewest on M.26 under acidic soil condition in Poland. Przemysla and Maciej (2006) also found similar results for 'Jonica' cultivar grown on M.9 rootstock, after P.22 and P.29 rootstocks in Krakowa, Poland.

\section{Conclusion}

Anna and Jonagored grafted on MM.111rootstock had maximum trunk growth, highest number of flowers and fruits in soil $\mathrm{pH}$ of 3.5. On the contrary, both Anna and Jonagored grown on M.9 under soil $\mathrm{pH}$ of $6.3 \& 4.9$ recorded highest trunk growths more flowers and fruits in ranking order. Low soil $\mathrm{pH}$ of 4.9 significantly $(\mathrm{P}<0.001)$ influences the growth and yield of both cultivars under study compared to $\mathrm{pH} 6.3$.

Under experimental site of Chencha with $\mathrm{pH}$ of 4.9 Anna was the most productive on MM.111 while least on MM.106. Conversely, Jonagored was most productive on M.9 and MM.106, but least on MM.111. Thus, MM.111 was not recommended for grafting with Jonagored. In pH 6.3 both cultivars were recommended to grow on M.9.

\section{ACKNOWLEDGEMENTS}

The author would like to thank Gammo kalehiwot protestant church for allowing me the farm land and Addis Ababa University Eco-Physiology and JiJe pvt. Itd Laboratory for their invaluable contributions to this research.

\section{REFERENCES}

CSA (2010). Agricultural Sample Survey. Statistical Bulletin 468, Addis Ababa Duncan, D. B. (1955). Multiple range and multiple $F$ tests, Biometrics. 11: 1-42.

Esmaeil, F., Chun, I. J. Gerry, H. N. and Michael, C. W. (2001). Effects of three Rootstocks on photosynthesis, leaf mineral nutrition, and vegetative growth of "BC-2 Fuji" apple trees, Journal of Plant Nutrition. 24: 827-834.

Esmaeil, F., Michael, C. W., Bahr, F., and Ik-Jo Chun (2002). The importance of apple rootstocks on tree growth, yield, fruit quality, leaf nutrition, and photosynthesis with an emphasis on Fuji. Hort Technology 12 (1):38-44.

Frank, G. and Dennis, J. (1996). Fruit development. In: Tree fruit physiology: growth and development, pp. 107-116, (Karen, M. M, Preston, K. A., Gregory, A. L., Kent, M. eds). Publ. Good Fruit Grower, Yakima, Washington. Kamboj, J.S., Browning, G., Quinlan, J.D., Blake, P.S. Baker, D.A. (1997). Polar transpor of [3H]-IAA in apical shoot segments of different apple rootstocks.J. Hortic. Sci., 72:773-780.

Meland, M. (2009). Effects of different crop loads and thinning times on yield, fruit quality, and return bloom in Malus x domestica Borkh. 'Elstar. Journal of Horticultural Science \& Biotechnology ISAFRUIT Special Issue 117-121.

Mohammad, R. D., Mohammad, J. S., Zeinab, H. and Ahmad, D. (2012). Effects of M.9 and MM.106 rootstocks on agro morphological characteristics of 'Golab kohanz' and 'Delbarstival' apple cultivars in Abhar region of Iran. Indian Journal of Science and Technology. 5(1): 1844-1847. 
Neeme, U., Toivo, U., Krista, T. (2006). Effect of five rootstocks on growth and yield of four apple cultivars in young orchard. Polli horticultural research center of the institute of agricultural and environmental sciences. Estonia University of life sciences. 25 (3): 192-198.

Peter, M. H. and David, C. F. (1995). Rootstock Effects on the Flowering of 'Delicious'Apple. II. Nutritional Effects with Specific Reference to Phosprus.

Ohio Agricultural Research and Development Center, The Ohio State University, Wooster, OH 44691. J. Amer. Soc. Hort. Sci. 120(6):1018-1024.

Przemyslaw, B. and Maciej, G.(2006). Growth and fruiting of apple tree cv. 'Jonica'on different rootstocks. Scientific works on Lithuanian university ofagriculture. 25 (4): 54-61.

Sas Paszt, L. and Mercik, S. (2004). The response of apple rootstocks P.22, M.9 and M.26, and apple tree cultivars Jonagold and Gala to soil acidification. Acta Hort. (ISHS) 636:167-172.

Sotiropoulos, T. E. (2008). Performance of the apple (Malus domestica Borkh) cultivar Imperial Double Red Delicious grafted on five rootstocks. Hort. Sci. (Prague). 35 (1): 7-11.

Soumelidou, K., Morris, D. A., Battey, N.H., Barnett, J. R . (1994b). Auxin transport capacity in relation to the dwarfing effect of apple rootstocks. J. Hort. Sci. 69: 719-725.

Tahereh, P., Hossein, A., and Abdolghafar, E. (2011). A study of the influence of different rootstocks on the vegetative growth of cultivars. African Journal of Biotechnology .10(74):16808-16812.

Webster, A. D. (2005). Sites and soils for temperate tree-fruit production: their selection and amelioration. In: Fundamentals of Temperate Zone Tree Fruit Production (J.Tromp, A.D. Webster and S. J. Wertheim, eds) Backhuys publishers, Leiden, The Netherlands.

Westwood, M. N. (1993). Temperate zone pomology physiology and culture. Third edition. Timber Press, Port land, Oregon.

Wesley, R. A. and James, K. (2001). Rootstock Effects on Ginger Gold Apple Trees Department of Plant \& Soil Sciences, University of Massachusetts. Fruit notes V.66

Yahya, R. Al-Hinai and Teryl, R. R. (2004). Rootstock Effects on Growth and Quality of Gala Apples. Hortic. Sci. 39(6): 1231-123. 